\title{
Upregulation of insulin receptor substrate-2 in pancreatic $\beta$ cells prevents diabetes
}

\author{
Anita M. Hennige, ${ }^{1}$ Deborah J. Burks, ${ }^{1}$ Umut Ozcan, ${ }^{2}$ Rohit N. Kulkarni, ${ }^{2}$ Jing Ye,${ }^{1}$ \\ Sunmin Park, ${ }^{1}$ Markus Schubert, ${ }^{1}$ Tracey L. Fisher, ${ }^{1}$ Matt A. Dow, ${ }^{1}$ Rebecca Leshan, ${ }^{1}$ \\ Mark Zakaria, ${ }^{1}$ Mahmud Mossa-Basha, ${ }^{1}$ and Morris F. White ${ }^{1}$
}

${ }^{1}$ Howard Hughes Medical Institute, Joslin Diabetes Center, Harvard Medical School, Boston, Massachusetts, USA
${ }^{2}$ Research Division, Joslin Diabetes Center, Harvard Medical School, Boston, Massachusetts, USA

The insulin receptor substrate-2 (Irs2) branch of the insulin/IGF signaling system coordinates peripheral insulin action and pancreatic $\beta$ cell function, so mice lacking Irs 2 display similarities to humans with type 2 diabetes. Here we show that $\beta$ cell-specific expression of Irs 2 at a low or a high level delivered a graded physiologic response that promoted $\beta$ cell growth, survival, and insulin secretion that prevented diabetes in Irs2 ${ }^{-/-}$mice, obese mice, and streptozotocin-treated mice; and that upon transplantation, the transgenic islets cured diabetes more effectively than WT islets. Thus, pharmacological approaches that promote Irs 2 expression in $\beta$ cells, especially specific cAMP agonists, could be rational treatments for $\beta$ cell failure and diabetes.

J. Clin. Invest. 112:1521-1532 (2003). doi:10.1172/JCI200318581.

\section{Introduction}

Diabetes mellitus arises from dysregulated glucose sensing or insulin secretion (mature onset diabetes of youth, or MODY), autoimmune-mediated $\beta$ cell destruction (type 1), or insufficient compensation for peripheral insulin resistance (type 2) (1). As insulin resistance develops, type 2 diabetes is avoided by expanding functional $\beta$ cells that secrete sufficient insulin quickly enough to maintain glucose homeostasis. Diet, acute or chronic stress, and obesity are major determinants of peripheral insulin sensitivity, and age exacerbates these environmental effects. While it is clear that insulin resistance and $\beta$ cell dysfunction contribute to type 2 diabetes, there is considerable debate regarding the relative importance of these two abnormalities $(2,3)$. Studies with humans and rodents reveal a tightly controlled inverse relationship between insulin sensitivity and insulin secretion, suggesting that a feedback mechanism balances $\beta$ cell function with the prevailing level of peripheral insulin sensitivity (3). When $\beta$ cell compensation fails, glucose intolerance and type 2 diabetes develop, but the mechanisms involved and whether they are linked at the molecular level are unknown (4).

How insulin sensitivity influences insulin secretion is poorly understood. Recent work with transgenic mice

Received for publication April 8, 2003, and accepted in revised form September 16, 2003.

Address correspondence to: Morris F. White, Howard Hughes Medical Institute, Joslin Diabetes Center, 1 Joslin Place, Boston, Massachusetts 02215, USA. Phone: (617) 732-2578;

Fax: (617) 732-2593; E-mail: whitemor@whitelabs.org.

Conflict of interest: The authors have declared that no conflict of interest exists.

Nonstandard abbreviations used: mature onset diabetes of youth (MODY); insulin receptor substrate (Irs); rat insulin II promoter (rip); murine genome (MG); glucose transporter-2 (Glut2); area under the curve (AUC). suggests that $\beta$ cell function is regulated by insulin and IGF signaling (5). The receptors for insulin and IGF1 promote phosphorylation of the insulin receptor substrates, Irs1 and Irs2, which engage various downstream pathways, including the Grb2/Sos $\rightarrow$ ras and the PI3K $\rightarrow$ Akt cascades (6-8). Although these pathways were originally described in heterologous cell lines and peripheral tissues, recent work suggests that they play a central role in $\beta$ cell function. Insulin action and secretion are closely linked at the molecular level through the Irs2 branch of the insulin/IGF signaling cascade $(9,10)$. Global disruption of Irs 2 causes peripheral insulin resistance that is compensated for by relative hyperinsulinemia early in life; however, Irs $2^{-1-}$ mice progress toward diabetes as $\beta$ cell mass decreases and insulin secretion fails $(9,11-13)$. By contrast, peripheral insulin resistance caused by obesity or by disruption of Irs 1 is compensated for, at least in part, by expansion of $\beta$ cell mass $(9,14)$. Disruption of the receptors for insulin or IGF1 in $\beta$ cells impairs first-phase insulin secretion, which contributes to glucose intolerance (11-13). Together these results suggest that the Irs2 branch of the insulin/IGF signaling pathway is essential for $\beta$ cell function throughout life.

Identifying a single genetic defect that causes insulin resistance and $\beta$ cell failure has been difficult to accomplish, leading many investigators to conclude that ordinary type 2 diabetes is a polygenic disorder (3). By contrast, disruption of Irs 2 in mice reveals a single defect that causes both insulin resistance and $\beta$ cell dysfunction that culminates in diabetes $(9,15)$. Mutations in IRS2 are unusual and probably not associated with common type 2 diabetes in people (16). However, genetic polymorphism or environmental stress that compromises Irs2 function or diminishes its downstream signals might explain the heterogeneity of common type 2 diabetes in terms of a defined signaling cascade. 
Since Irs 2 plays an important role in $\beta$ cell function, we reasoned that its upregulation might prevent diabetes under conditions that cause insulin resistance or physiological stress. To test this hypothesis, we generated transgenic mice expressing Irs 2 at a low or a high level in $\beta$ cells under the control of the rat insulin II promoter (rip). Our results show that Irs 2 expression prevents diabetes that results from a variety of causes.

\section{Methods}

Generation of rip $\rightarrow$ Irs2 transgenic mice. A 668-bp rip constructed in the PSP72 vector was kindly provided by Mark Magnuson (Vanderbilt University, Nashville, Tennessee, USA). The FLAG tag sequence was added to the $3^{\prime}$ end of mouse Irs 2 by PCR and the tagged cDNA was then inserted directly after the rip promoter using the NotI/HindIII sites. A linearized DNA fragment containing the rip-Irs 2 transgene was excised and microinjected into fertilized eggs of C57BL/ 6 mice according to standard techniques by the Beth Israel Deaconess Transgenic Mouse Facility (Boston, Massachusetts, USA). Germline transmission was confirmed by Southern blotting. Founders were bred with C57BL/6 mice and maintained on this pure background. Routine genotyping was executed by PCR using primers derived from the FLAG tag and an internal Irs2 sequence. Experiments were performed on mice of line 9 and line $13($ rip $9 \rightarrow[r s 2$ and rip $13 \rightarrow I r s 2)$ and their nontransgenic littermates. To obtain mice with a homozygous knockout for Irs2 that were rip-Irs2 transgene-positive $\left(\right.$ Irs $2^{-1-}:$ rip $^{\rightarrow I r s 2}$ ), we bred Irs $2^{+-}$:rip $\rightarrow$ Irs2 animals. All procedures were performed with male mice on a pure C57BL/ 6 background and in accordance with the policies of the Institutional Animal Care and Use Committee of Beth Israel Deaconess Medical Center and Harvard School of Public Health.

Pancreatic insulin content. Pancreata from euthanized mice were homogenized and protein was extracted twice overnight at $-20^{\circ} \mathrm{C}$ in acid-ethanol and stored at $-20^{\circ} \mathrm{C}$. The extracts were combined and the immunoreactive insulin levels were measured by ELISA (Crystal Chem Inc., Downers Grove, Illinois, USA) with mouse insulin as a standard.

Min6 cell culture and analysis. Min6 cells were used between passages 19 and 30, and grown in high-glucose DMEM containing $15 \%$ (vol/vol) heat-inactivated FBS, $50 \mu \mathrm{M} \beta$-mercaptoethanol, $50 \mathrm{U} / \mathrm{ml}$ penicillin, and $10 \mu \mathrm{g} / \mathrm{ml}$ streptomycin. Min $6 \beta$ cells were cultured in a humidified atmosphere at $37^{\circ} \mathrm{C}$ with $5 \%$ $\mathrm{CO}_{2}$. At $80 \%$ confluence, cells were washed with PBS and incubated in serum-free medium for 8 hours without compound or with exendin-4 or dibutylcAMP. After the treatment, cells were harvested in icecold PBS and lysed in $20 \mathrm{mM}$ Tris ( $\mathrm{pH}$ 7.4) containing $2 \mathrm{mM}$ EDTA, $137 \mathrm{mM} \mathrm{NaCl}, 1 \% \mathrm{NP}-40,10 \%$ glycerol, and $12 \mathrm{mM} \beta$-glycerol phosphate, $1 \mathrm{mM}$ PMSF, and 10 $\mathrm{mg} / \mu \mathrm{l}$ leupeptin and aprotinin. After 30 minutes on ice, the lysates were centrifuged for 10 minutes at $14,000 \mathrm{~g}$ at $4^{\circ} \mathrm{C}$. After determining protein content, equal amounts of total protein $(200 \mu \mathrm{g})$ were incubated with anti-Irs 2 antibody, precipitated on immobilized protein G, resolved by SDS-PAGE, and immunoblotted with anti-Irs2.

Islet preparation. Isolated islets were obtained by collagenase P digestion of pancreata removed from WT,

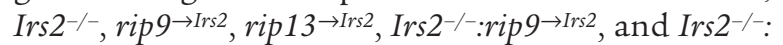
rip $13 \rightarrow$ Irs 2 mice (17). Overnight-fasted mice, aged 6-10 weeks, were anesthetized by intraperitoneal injection with Avertin ( $1.0 \mathrm{ml} / 40 \mathrm{~g}$ body wt). About $2.0 \mathrm{ml}$ of a collagenase solution $(0.8 \mathrm{mg} / \mathrm{ml}$ in RPMI 1640) was injected into the bile duct to inflate the pancreas. After the pancreas was removed, the tissue was incubated at $37^{\circ} \mathrm{C}$ for 30 minutes to complete the digestion. Following digestion, islets were selected from the media and washed once in RPMI with $10 \% \mathrm{FBS}$, then twice in RPMI without FBS. Following isolation, islets were either suspended in CMRL 1066 supplemented with 10\% FBS and antibiotics and then cultured in $37^{\circ} \mathrm{C}$ in a $\mathrm{CO}_{2}$ incubator for further experiments, or quickly frozen in liquid nitrogen for protein extraction, SDS-PAGE, and immunoblotting. In some experiments, 200 islets were pelleted for mRNA isolation and GeneChip analysis.

RNA isolation, cRNA preparation, and array bybridization. WT mice aged 4-6 weeks displaying normal fasting and random-fed insulin and blood glucose levels were starved overnight, anesthetized in the morning by intraperitoneal injection with Avertin $(1.0 \mathrm{ml} / 40 \mathrm{~g}$ body wt), and used for the isolation of skeletal muscle $(300 \mathrm{mg})$, liver $(100 \mathrm{mg})$, adipose tissue $(150 \mathrm{mg})$, or brain (100 mg). Total RNA was isolated using Trizol (Invitrogen Corp., Chicago, Illinois, USA) and purified with RNeasy (Qiagen Inc., Los Angeles, California, USA), and mRNA was isolated using Oligotex (Qiagen Inc.). The SuperScript Choice System (Invitrogen Corp.) was used to prepare cDNA. Labeled cRNA $(15 \mu \mathrm{g})$ was made with the MEGAscript T7 high-yield transcription kit (Ambion Inc., Houston, Texas, USA), fragmented, and hybridized to Affymetrix murine genome (MG) $U 74 \mathrm{v} 2$ arrays $\mathrm{A}, \mathrm{B}$, and $\mathrm{C}$ according to the GeneChip Expression Analysis manual (Affymetrix Inc., San Francisco, California, USA). Islet samples were prepared using the GeneChip Eukaryotic Small Sample Target Labeling Assay, version 1 . Approximately $1 \mu \mathrm{g}$ of total RNA was isolated from about 200 islets collected from WT, rip $13^{\rightarrow I r s 2}$, or Irs $2^{-1-}$ :rip $13^{\rightarrow I r s 2}$ mice at 6 weeks of age. Approximately $100 \mathrm{mg}$ of RNA was amplified to obtain $15 \mu \mathrm{g}$ of cRNA for hybridization. All samples were hybridized and scanned at the Massachusetts Institute of Technology Center for Cancer Research/Howard Hughes Medical Institute Biopolymers Laboratory. The primary data was analyzed with Affymetrix GeneChip (version 5). The trimmed mean signals of the probe arrays were scaled to a value of 500 . GeneSpring (version 5.0; Silicon Genetics, Redwood City, California, USA) was used to annotate the results and normalize each chip and gene - except those marked absent until the medians converged. 
Analysis of signaling proteins in isolated islets. Isolated islets incubated for 12 hours in CMRL 1066 containing 10\% FCS were used to determine total protein levels and/or the phosphorylation states of Akt1/2, Foxo1, Erk1/2, and cleaved caspase-3. Subsequently, the islets were starved for 3 hours in CMRL 1066 without serum. The islets were then cultured in the absence or presence of IGF1 (100 nM) for 20 minutes. The islet lysates were boiled for 5 minutes in SDS sample buffer and resolved by $12 \%$ SDS-PAGE for $2-3$ hours at $100 \mathrm{~V}$ and transferred to a nitrocellulose membrane for immunoblotting. The membranes were incubated overnight with primary antibodies at $4^{\circ} \mathrm{C}$ (Cell Signaling Technology Inc., Beverly, Massachusetts, USA), washed with TBST for 30 minutes, incubated for 1 hour with HRP-conjugated secondary antibodies, and finally washed thoroughly and subjected to enhanced chemiluminescence (NEN Life Science Products Inc., Boston, Massachusetts, USA).

Islet morphology and immunohistochemistry. For immunohistochemistry, pancreatic sections were fixed for 16 hours in $4 \%$ paraformaldehyde and then transferred to PBS until embedding in paraffin as previously described (18). Following rehydration and permeabilization with $1 \%$ Triton $\mathrm{X}-100$, sections were incubated overnight at $4{ }^{\circ} \mathrm{C}$ with antibodies targeted to specific proteins of interest as previously described (18). Transgenic Irs2 was detected with anti-FLAG (Eastman Kodak Co., New Haven, Connecticut, USA), insulin was detected with guinea pig anti-insulin (Zymed Laboratories Inc., South San Francisco, California, USA), glucose transporter-2 (Glut2) was detected with rabbit anti-Glut2 antibodies (CalbiochemNovabiochem Corp., San Diego, California, USA), and glucagon was detected with anti-glucagon (Zymed Laboratories Inc.). The anti-FLAG antibody was detected with secondary antibodies conjugated to cyanine. The other antibodies were detected with fluorescene-tagged secondary antibodies. To minimize variability between different sections, the staining procedures for the sections were performed in parallel with the same batches of solutions and antisera. In addition, the same incubation times for fixation, permeabilization, blocking, and exposure to antisera were strictly used for all processed sections.

Islet proliferation was estimated by injecting 8week-old male mice with $100 \mu \mathrm{g} / \mathrm{g}$ body wt BrdU (Roche Molecular Biochemicals, Indianapolis, Indiana, USA), and pancreas sections were analyzed by double staining with anti-insulin and anti-BrdU (Roche Molecular Biochemicals) (18). Apoptotic cells were identified in deparaffinized sections using a rhodamine DNA fragmentation detection assay (Intergen Co., Atlanta, Georgia, USA) (19). For quantification of $\beta$ cell area, sections were viewed using a Zeiss Axiovert S100 TV microscope (Carl Zeiss Inc., Thornwood, New York, USA) at a magnification of $\times 10$. Cross-sectional area of islets with more than five insulin-positive cells was measured with at least three sections (separated by $200 \mu \mathrm{m}$ ) per animal using
Openlab Image analysis software (Improvision Inc., Lexington, Massachusetts, USA). The results are expressed as the percentage of the total area of each pancreatic section. The ratio of $\beta$ cells to $\alpha$ cells was calculated from mean insulin- and glucagon-positive cell areas measured by double immunostaining.

Metabolic studies and mouse diet. Mice were fed ad libitum with a standard 9\% fat diet (5058; Purina Mills Inc., St. Louis, Missouri, USA) and kept under a lightdark cycle of 12 hours. When stated, mice were weaned on a high-fat diet (45 kcal\% fat) or low-fat diet (10 kcal\% fat) for 60 days (D12451 and D12450B, respectively; Research Diets, New Brunswick, New Jersey, USA). Glucose levels were sampled from mouse tail bleeds using a Glucometer Elite (Bayer Corp., Elkhart, Indiana, USA). Plasma insulin levels were determined using a competitive ELISA (Crystal Chem Inc.). Glucose tolerance tests were performed on mice after a 16-hour overnight fast. Animals were injected intraperitoneally with D-glucose $(2 \mathrm{~g} / \mathrm{kg})$, and blood glucose concentrations were determined at indicated times. Glucose-stimulated insulin release was measured in fasted mice injected intraperitoneally with Dglucose $(3 \mathrm{~g} / \mathrm{kg})$. As indicated, mice were subjected to an intraperitoneal injection of low-dose streptozotocin $(40 \mathrm{mg} / \mathrm{kg}$ body wt dissolved immediately before administration in $0.1 \mathrm{M}$ citrate buffer, $\mathrm{pH} 4.5$ ) for 5 consecutive days.

Islet transplantation. Mice were made diabetic by daily injections of streptozotocin for 3 days $(100 \mathrm{mg} / \mathrm{kg}$ body wt dissolved immediately before administration in $0.1 \mathrm{M}$ citrate buffer, $\mathrm{pH} 4.5$ ) as previously described (20). Islets used for transplantation were isolated from healthy male 8-week-old mice as described previously using intraductal Liberase (Roche Molecular Biochemicals) perfusion to release islets from the pancreas tissue for manual selection under a stereomicroscope (Stereozoom GZ7; Leica Microsystems Inc., Deerfield, Illinois, USA) (20). Following isolation, islets were kept on ice until transplantation into diabetic mice. Surgery was performed under anesthesia by using a 1:1 mixture of 2,2,2-tribromoethanol and tert-amyl alcohol and diluted 1:50 in PBS ( $\mathrm{pH}$ 7.4). Using a retroperitoneal approach, the capsule of one of the kidneys was incised, and the islets were implanted near the upper pole in 8-week-old male mice. The capsule was cauterized, and the mice were allowed to recover on a heating pad.

Statistical analysis. Results are expressed as mean \pm SEM. For comparison between two groups, the unpaired Student $t$ test (two tailed) was used when appropriate; $P$ values less than 0.05 were considered significant. To quantify the difference between glucose tolerance tests or glucose-stimulated insulin secretion, the area under the curve (AUC) was calculated by the trapezoid rule using SigmaPlot 8.02 (SPSS Inc., Chicago, Illinois, USA). The mean AUC \pm SEM was determined from at least five individual curves for each experimental condition reported. 
a
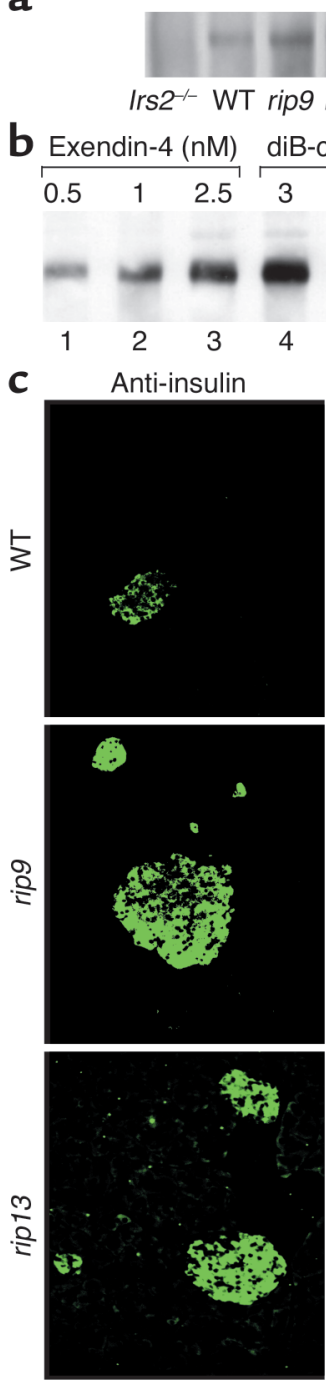

$\leftarrow$ Irs2

( $(\mu \mathrm{M})$

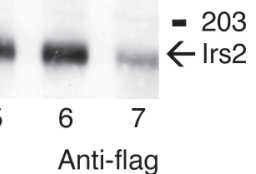

$\leftarrow$ Irs2
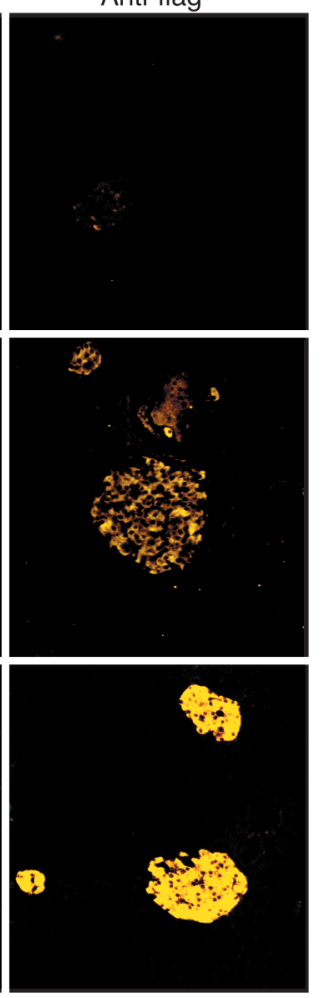
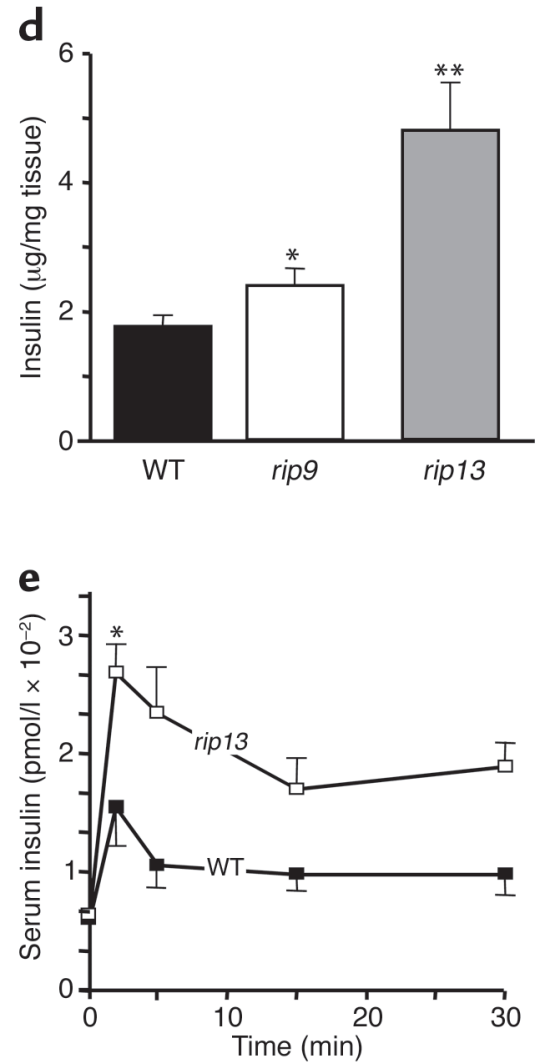

f

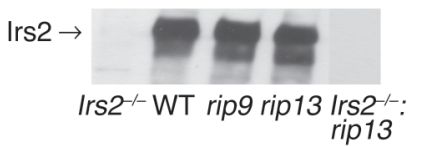

\section{Figure 1}

Irs2 protein expression and $\beta$ cell function. (a) Irs2 protein levels measured by specific immunoblotting in Irs 2 immunoprecipitates of $200 \mu \mathrm{g}$ total protein from islet extracts of 4-week-old WT mice, Irs $2^{-/-}$mice, or two lines of transgenic mice $\left(r i p 9^{\rightarrow / r s 2}\right.$ and rip $13^{-1 / r s}$ ). (b) Irs 2 protein levels measured by specific immunoblotting in Irs 2 immunoprecipitates of $200 \mu \mathrm{g}$ total protein from Min 6 cells treated for 8 hours with the indicated concentrations of exendin- 4 or dibutyl-cAMP (diB-cAMP) (c) Representative WT, rip9 $\rightarrow$ rrs 2 , or rip $13 \rightarrow$ rs 2 pancreas sections immunostained with anti-insulin antibodies (left panel) or anti-FLAG antibodies (right panel) that were detected by cyanine (Irs2) or fluorescein (Insulin) conjugated secondary antibodies, respectively. Original magnification, $\times 100$. (d) Pancreatic insulin content per mg total pancreas was measured in acid/ethanol extracts of total pancreas from 6 -month-old WT, rip $9^{\rightarrow / r s}$, and rip $13 \rightarrow$ rs 2 mice. Data are the mean values \pm SEM of five mice per genotype. ${ }^{*} P<0.05,{ }^{*} P<0.01$. (e) Glucose-stimulated insulin release measured in 6-week-old WT and rip $13 \rightarrow / r s 2 \mathrm{mice}$. D-glucose ( $3 \mathrm{~g} / \mathrm{kg}$ body wt) was injected intraperitoneally into 16-hour-fasted mice and blood samples were collected at the indicated timepoints. Results are expressed as mean values \pm SEM of six WT and six rip ${ }^{\rightarrow / r s} 2$ mice $\left({ }^{*} P<0.05\right)$. (f) Irs2 protein levels measured by specific immunoblotting in Irs 2 immuno-

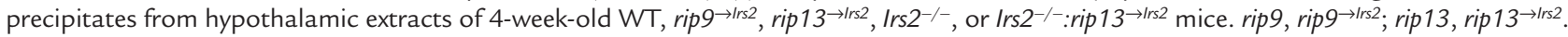

\section{Results}

Upregulation of Irs 2 in $\beta$ cells. To determine whether $\beta$ cell dysfunction is a pivotal element in the development of diabetes in Irs $2^{-/-}$mice, we generated transgenic C57BL/6 mice expressing a low $($ rip $9 \rightarrow$ Irs 2$)$ or a high $\left(\right.$ rip $\left.13^{\rightarrow I r s 2}\right)$ level of Irs 2 in pancreatic $\beta$ cells under the control of rip. Irs2 was measured by specific immunoblotting of islet extracts containing equal amounts of total protein (Figure 1a). Irs2 was detected in WT islet extracts but was undetectable in
Irs $2^{-/-}$islets. Concurrent immunoblots revealed twofold and 12-fold increased Irs2 in rip $9^{\rightarrow I r s 2}$ and rip13 $\rightarrow$ Irs 2 extracts (Figure 1a), which was similar to that obtained physiologically by activation of the endogenous Irs 2 promoter with functional cAMP response element binding protein (21). Moreover, the relative increase of transgenic Irs 2 in islets was comparable to the upregulation of endogenous Irs2 in Min $6 \beta$ cells treated for 10 hours with exendin- 4 or dibutyl-cAMP (Figure 1b). 

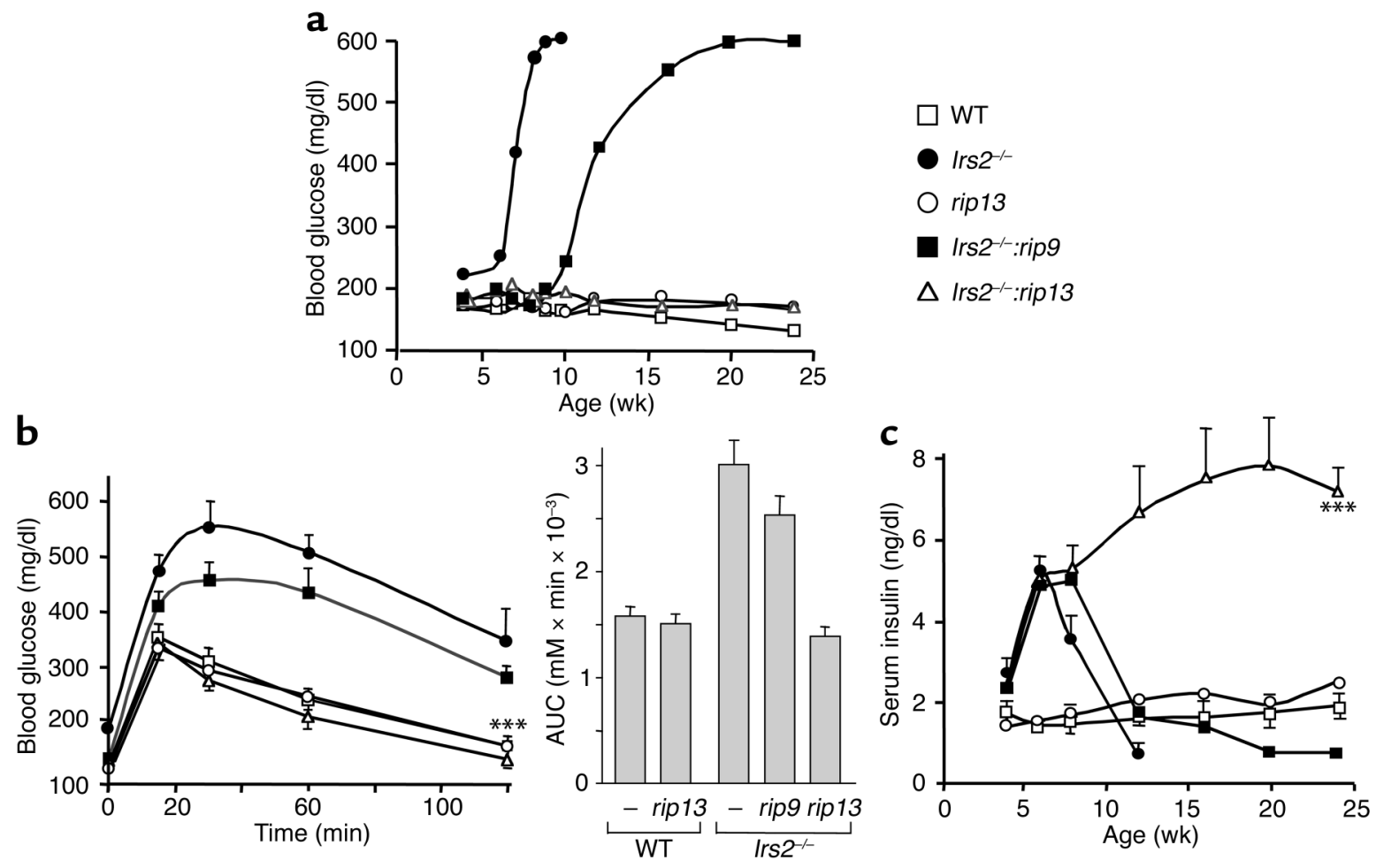

Figure 2

Metabolic effects of Irs 2 overexpression in $\beta$ cells. (a) Blood glucose concentrations were measured from tail bleeds of fed male mice. Values are

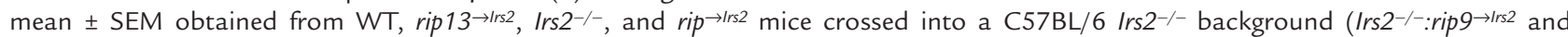

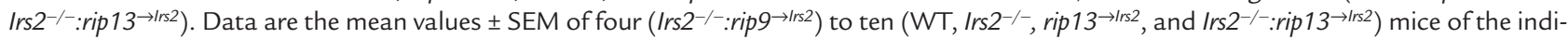
cated ages. (b) Glucose-tolerance tests were performed on 8-week-old fasted mice following intraperitoneal loading with $2 \mathrm{~g} \mathrm{D}$-glucose per kg body wt. Blood samples were taken at the timepoints indicated and glucose was determined as described. Results are mean \pm SEM of four to ten mice $\left({ }^{* *} P<0.001\right.$, Irs $2^{-/-}$vs. Irs $2^{-/-}:$rip $133^{-1 r s}$ ). . (c) Random-fed serum insulin levels (mean values \pm SEM, $\left.{ }^{* *} P<0.001\right)$ measured by ELISA.

Our transgenic production strategy incorporated a FLAG tag at the $\mathrm{C}$ terminus of Irs2 to facilitate immunostaining. Pancreas sections immunostained with anti-FLAG antibodies revealed that recombinant Irs2 protein was restricted to the insulin-positive $\beta$ cells in rip $9 \rightarrow[r s 2$ and rip $13 \rightarrow[r s 2$ islets (Figure 1c). Moreover, the pancreatic insulin content increased 1.3-fold in rip $9 \rightarrow \operatorname{Irs} 2$ mice and 2.7 -fold in rip $13 \rightarrow$ Irs 2 mice, revealing a dose effect of Irs 2 expression on $\beta$ cell insulin content (Figure 1d). During an intraperitoneal glucose challenge, insulin secretion during the first 30-minute interval was threefold higher in rip $13^{\rightarrow \text { Iss } 2}$ mice than in WT mice (AUC WT: $1,880 \pm 50 \mathrm{nmol} \times \mathrm{min} / \mathrm{l}$; AUC rip13 $\rightarrow$ Irs2: $5,440 \pm 50 \mathrm{nmol} \times \mathrm{min} / \mathrm{l})($ Figure 1e). However, glucose homeostasis was normal in rip $13 \rightarrow I r s 2$ mice from birth until the experiment was terminated after 24 weeks, as fasting glucose never fell below $79 \pm 3 \mathrm{mg} / \mathrm{dl}$ and fed glucose never rose above $159 \pm 6 \mathrm{mg} / \mathrm{dl}$. Both transgenic mouse lines displayed normal fertility, growth, and adiposity, and had normal life spans (data not shown). Irs2 protein was never detected in hypothalamus (Figure 1f), nor was it detected in liver, muscle, or adipose tissues (data not shown).

Irs 2 in $\beta$ cells prevents diabetes in Irs $2^{-/-}$mice. Male C57BL/6 Irs $2^{-/-}$mice developed hyperglycemia between 4 and 6 weeks of age, which progressed to overt diabetes during the next 5-6 weeks until they died (Figure 2a). To determine whether the Irs 2 transgene prevented diabetes in the Irs $2^{-/-}$mice, we crossed rip $9 \rightarrow$ Irs2 or rip $13^{\rightarrow I r s 2}$ mice with Irs $2^{-/-}$mice. As expected, transgenic Irs 2 was expressed at a low level in Irs2 $2^{-1}:$ rip $9 \rightarrow$ Irs 2 islets and at a high level in Irs2--rip13 $\rightarrow$ Irs 2 islets (data not shown). Irs $2^{-/}:$:rip $9^{\rightarrow I r s 2}$ mice survived for 24 weeks because hyperglycemia progressed slowly toward diabetes between 10 and 24 weeks of age (Figure 2a). By contrast, glucose levels of Irs $2^{-1}:$ rip $13^{\rightarrow} \rightarrow$ Irs 2 mice were normal during the 24week experiment, revealing a dose effect for $\beta$ cell Irs 2 expression on glucose homeostasis (Figure 2a).

While Irs $2^{-/-}$mice at 8 weeks of age displayed fasting hyperglycemia (Irs2 $2^{--}: 189 \pm 10 \mathrm{mg} / \mathrm{dl}$; WT: $109 \pm 6 \mathrm{mg} / \mathrm{dl}$ ), Irs $2^{-/}$mice expressing the transgenic Irs2 were nearly normal (Irs2-/:rip9 $\rightarrow$ Irs2: $124 \pm 9$ $\mathrm{mg} / \mathrm{dl}$; Irs2 $2^{--}:$rip $13^{\rightarrow I r s 2}: 121 \pm 8 \mathrm{mg} / \mathrm{dl}$ ). As previously shown, the Irs $2^{-/-}$mice were severely hyperglycemic during an intraperitoneal glucose challenge (Figure $2 \mathrm{~b})$. However, at 8 weeks of age, glucose intolerance was slightly improved in the Irs $2^{--}:$rip $9^{\rightarrow}$ Irs 2 mice and completely normalized in the Irs2 $2^{-}$:rip $13^{\rightarrow I r s}$ mice (Figure $2 \mathrm{~b}$ ). Moreover, the Irs $2^{-/}$:rip $13^{\rightarrow I r s 2}$ mice survived more than a year after the Irs $2^{-/-}$mice died, displaying low random fed blood glucose levels at 15 months (WT: $121 \pm 7 \mathrm{mg} / \mathrm{dl}$; Irs2 $2^{--}:$rip $13^{\rightarrow I r s 2}: 94 \pm 6 \mathrm{mg} / \mathrm{dl}$ ). 
a
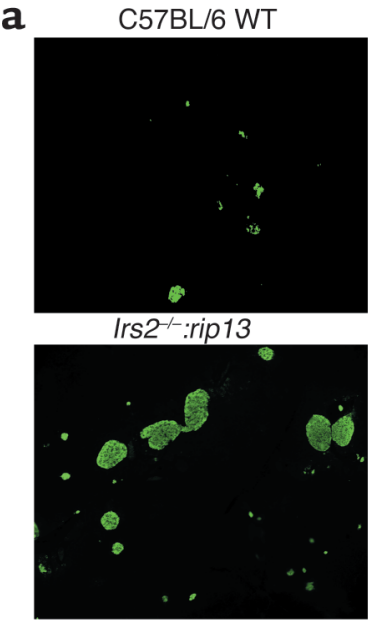

b

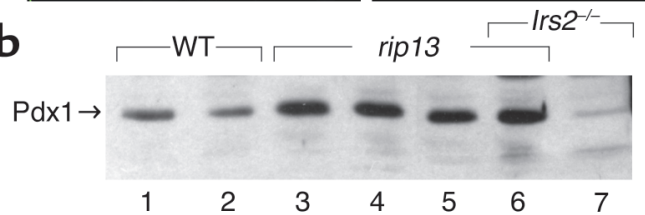

Figure 3

Islet morphometry. (a) Insulin immunostaining of representative pancreas sections from 8-week-old C57BL/6 mice and from rip13 $\rightarrow^{\mid r s 2}$, Irs2 $2^{-/-} /$rip $3^{\rightarrow / r s 2}$, and Irs $2^{-/-}$mice (original magnification, $\times 100$ ). (b) Western blot of $\mathrm{Pdx} 1$ protein expression in isolated islets from 4-week-old male mice of the indicated genotypes. Each lane was loaded with $100 \mu \mathrm{g}$ of total islet protein from one animal and is representative of at least three independent experiments.

Irs $2^{-/-}$mice are insulin resistant as a result of reduced insulin action in liver, fat, and muscle $(9,22)$. Before diabetes developed at 6 weeks, serum insulin levels were equally elevated in $\operatorname{Irs} 2^{-1-}, \operatorname{Irs} 2^{-1-}:$ rip $9^{9 \rightarrow \operatorname{Irs} 2}$, and Irs2 $2^{-1}:$ rip $13^{\rightarrow}$ Irs 2 mice to compensate for insulin resistance (Figure 2c). Insulin levels declined dramatically in Irs $2^{-/-}$mice at 8 weeks, coinciding exactly with the onset of severe diabetes (Figure 2c). Compensatory insulin secretion in Irs $2^{--}$:rip $9 \rightarrow I r s 2$ mice gradually declined between 12 and 25 weeks until they died with severe diabetes (Figure 2c). Irs2 ${ }^{--}$:rip $13 \rightarrow I r s 2$ mice never developed diabetes due to persistent compensatory hyperinsulinemia, revealing the graded physiological response to Irs 2 expression in transgenic $\beta$ cells func- tioning in a genetically insulin resistant mouse (Figure $2 \mathrm{c}$ and data not shown).

Irs 2 promotes $\beta$ cell development and growth. Our previous work suggests that Irs 2 signaling regulates survival of pancreatic $\beta$ cells $(18,19)$. Compared with WT mice at 8 weeks of age, islet area in Irs $2^{-/-}$pancreas sections was reduced about threefold, owing to a slightly reduced density of small islets containing 50\% fewer $\beta$ cells (Figure 3a and Table 1). By contrast, islet area in the rip13 $\rightarrow$ Irs 2 sections increased twofold, mainly due to increased density of normal-sized islets (Table 1). Islet density and the $\beta$ cell content increased in Irs2 $2^{-1}$ :rip $13^{\rightarrow \text { Irs } 2}$ mice, a change that was also revealed by the increased ratio of $\beta$ cells to $\alpha$ cells (Table 1 ).

To determine whether $\beta$ cells in Irs $2^{--}:$rip $13^{\rightarrow} \rightarrow$ Irs 2 islets were dividing at a higher rate than those in WT or rip13 $\rightarrow$ Irs 2 islets, we injected 8-week-old mice with the thymidine analogue $\mathrm{BrdU}$ to measure mitogenesis. BrdU incorporation into $\beta$ cells during a 6-hour interval increased three- to fourfold in Irs $2^{--}:$rip $13^{\rightarrow \text { Irs } 2}$ mice compared with WT or rip13 $\rightarrow$ Irs mice; no BrdU-positive cells were detected in Irs $2^{-/-}$mice (Table 1). The average $\beta$ cell size never changed upon expression of the Irs 2 transgene. Thus, compensatory islet expansion during insulin resistance required Irs 2 signaling to increase the number of normal-sized $\beta$ cells.

The effect of Irs 2 upregulation on islet gene expression. A possible mechanism by which Irs2 promotes expansion of $\beta$ cells is through upregulation of the homeodomain transcription factor $P d x 1$ (also called $I d x 1$ and Ipf1). $P d x 1$ is critical for development of the pancreas in mice and humans, and its complete disruption blocks pancreas development; in adult $\beta$ cells, $P d x 1$ promotes normal glucose sensing and insulin secretion, and suppresses apoptosis (18, 23-25). Previous results show that $P d x 1$ expression is nearly lost in Irs $2^{-/}$islets, but can be restored by downregulation of Foxo1 (10). Pdx1 was detected equally by immunoblotting in WT and rip $9^{\rightarrow I r s 2}$ islets (data not shown), whereas it was barely detected in our Irs2-/islet extracts of equal protein concentration (Figure $3 b)$. Consistent with a specific role for Irs 2 in Pdx1 expression, $\mathrm{Pdx} 1$ protein was strongly upregulated rip13 $\rightarrow$ Irs2 in WT and Irs $2^{-/}$mice containing the rip13 $\rightarrow$ Irs2 transgene. (Figure 3b). Since upregulation

Table 1

Islet characteristics

\begin{tabular}{|c|c|c|c|c|c|}
\hline & $\begin{array}{l}\text { Islet area } \\
\text { (\% of total) }\end{array}$ & $\begin{array}{c}\text { Density } \\
\text { (islets } / \mathrm{mm}^{2} \text { ) }\end{array}$ & $\beta$ cells/islet & $\beta / \alpha$ & $\begin{array}{c}\mathrm{BrdU} \\
(\%)\end{array}$ \\
\hline WT & $2.2 \pm 0.3$ & $1.3 \pm 0.2$ & $22 \pm 2$ & $10.4 \pm 0.5$ & $0.7 \pm 0.1$ \\
\hline rip13 $\rightarrow$ Irs2 & $4.3 \pm 0.4^{A}$ & $2.0 \pm 0.2^{\mathrm{A}}$ & $28 \pm 0.2$ & $28 \pm 4^{B}$ & $0.8 \pm 0.1$ \\
\hline Irs2 $2^{-/-}:$rip13 $\rightarrow$ Irs2 & $5 \pm 1^{\mathrm{B}}$ & $1.9 \pm 0.3^{\mathrm{A}}$ & $55 \pm 9^{B}$ & $46 \pm 6^{B}$ & $2.5 \pm 0.7^{\mathrm{B}}$ \\
\hline $\operatorname{lrs} 2^{-/-}$ & $0.6 \pm 0.1$ & $1.0 \pm 0.2$ & $12 \pm 1$ & $6 \pm 1$ & ND \\
\hline
\end{tabular}

Islet area was determined by point-counting morphometry and number of $\beta$ cells per islet was calculated from the number of nuclei in insulin-positive cells in each islet. Islet density was determined by counting islets with more than five $\beta$ cells; the $\beta$ cell $/ \alpha$ cell ratio $(\beta / \alpha)$ was determined directly by point-counting morphometry from sections immunostained with antibodies against glucagon and insulin. BrdU incorporation analysis was performed on double-labeled sections and is expressed as percentage BrdU-positive $\beta$ cells. Results are expressed as mean \pm SEM of six mice per genotype. ${ }^{A} P<0.01$, ${ }^{B} P<0.001$. ND, not determined. 


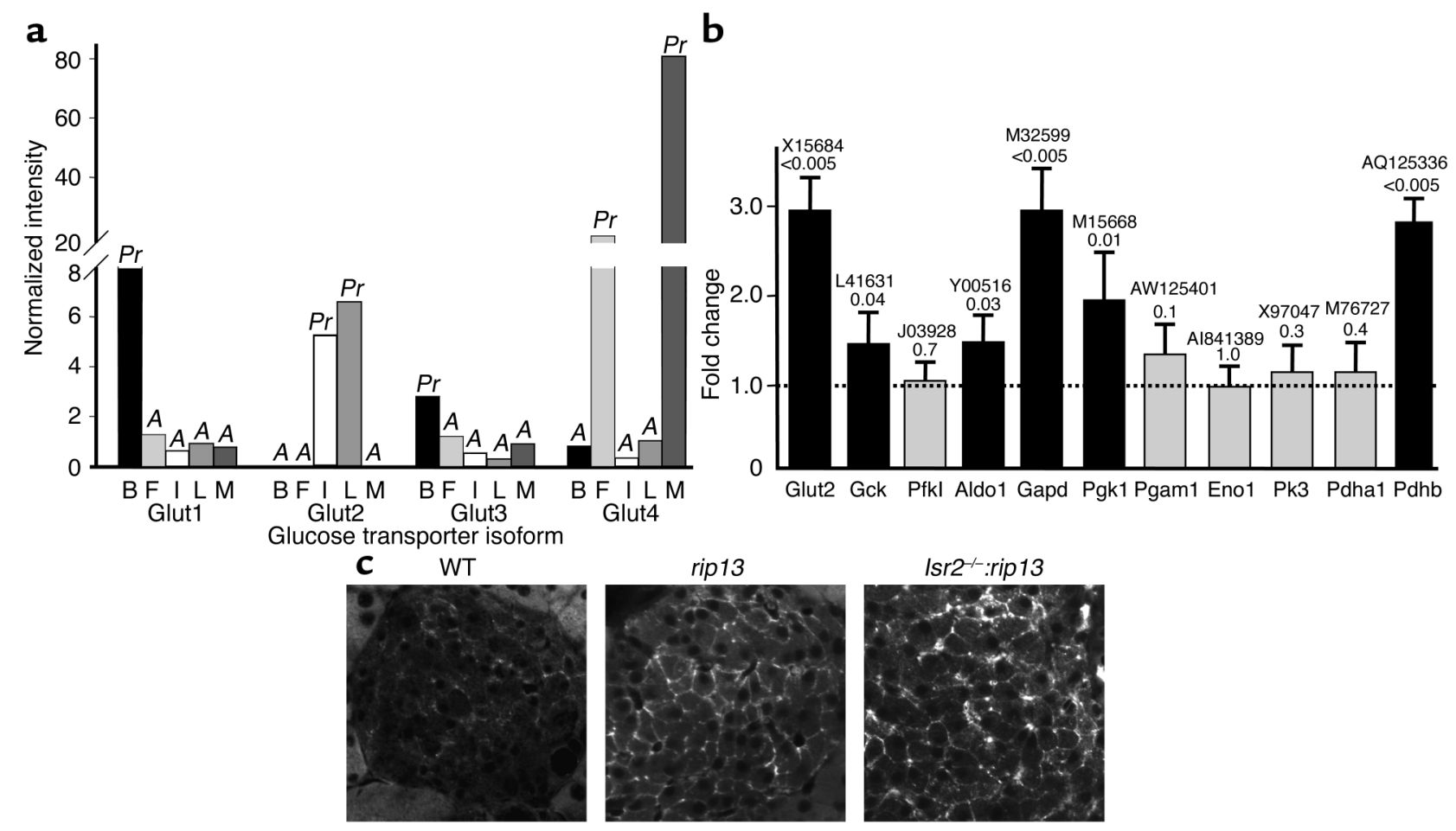

\section{Figure 4}

Gene expression in WT tissues and rip13 $\rightarrow$ rs 2 islets. (a) Affymetrix MG-U74v2 arrays (A, B, and C arrays) were used to estimate the relative mRNA levels for Glut1 (93738_at), Glut2 (103357_at), Glut3 (93804_at), and Glut4 (102314_at) in 6-week-old WT brain (B), adipose (F), rip13 $\rightarrow$ rs 2 islets $(\mathrm{I})$, liver $(\mathrm{L})$, and muscle $(\mathrm{M})$; the Affymetrix probe set is indicated in parentheses. Genes called present $(P r)$ or absent $(A)$ by GeneChip (version 5 ) are indicated on the figure. The bars show averages of normalized expression measurements obtained from samples of two mice. (b) The fold change for mRNA in rip13 $\rightarrow$ rs 2 islets normalized against WT islets is shown for Glut2, enzymes of the glycolytic pathway (glucokinase, Gck; phosphofructokinase-1, Pfk1; aldolase-1, Aldo1; GAPDH, Gapd; phosphoglycerokinase, Pgk1; phosphoglyceromutase-1, Pgam 1; enolase, Eno1; pyruvate kinase, $P k 3$; pyruvate), and the pyruvate dehydrogenase $\alpha$ subunit (Pdha1) and $\beta$ subunit (Pdhb). The expression of each gene in rip $13^{\rightarrow r s} 2$ islets is reported relative to the normalized level in WT islets; the $P$ value for this comparison is indicated. The accession number for each enzyme is indicated above the $P$ value. (c) Glut2 immunostaining of pancreas sections from 8 -week-old WT, rip13 $\rightarrow$ rs 2 , and Irs $2^{-/-}:$rip $13^{\rightarrow / r s 2}$ mice (original magnification, $\times 400$ ).

of Pdx1 increases mitogenesis in Irs $2^{-/-}$islets, upregulation of $P d x 1$ might contribute to the increased number of $\beta$ cells in Irs2 $2^{-1}$ :rip $13^{\rightarrow}$ Irs $^{2}$ islets $(18,25)$.

$P d x 1$ is reported to upregulate the expression of many genes that promote glucose-stimulated insulin secretion, including Glut2 (26). We used Affymetrix MG-U74v2 arrays to estimate the change in Glut2 mRNA between WT and rip13 $\rightarrow$ Irs 2 islets. The specificity of the Glut2 probe set was validated against the Glut1, Glut2, Glut3, and Glut4 probes using samples from rip13 $\rightarrow$ Irs 2 islets, brain, fat, liver, and muscle (Figure $4 a)$. As expected, Glut 2 was detected in liver and in rip $13 \rightarrow$ Irs 2 islets, but absent in the other test tissues; Glut1 and Glut3 were restricted to brain; and Glut4 was expressed exclusively in adipose and muscle tissue (Figure 4a). Compared with WT islets, Glut2 mRNA increased threefold $(P<0.005)$ in rip $13 \rightarrow$ Irs 2 islets (Figure $4 \mathrm{~b}$ ). Immunostaining revealed Glut 2 in the plasma membrane of rip $13 \rightarrow$ Irs 2 and Irs2 $2^{--}:$rip $13^{\rightarrow I r s 2} \beta$ cells, whereas it was barely detected in the plasma membrane of WT islets (Figure 4c). The mRNA for other glycolytic enzymes also increased in rip $13 \rightarrow$ Irs 2 islets, including glucokinase (1.5-fold, $P=0.04$ ), aldolase- 1 (1.5-fold, $P=0.03$ ), GAPDH (threefold, $P<0.005$ ), and Pgk-1 (1.9-fold, $P=0.01$ ); the $\beta$ subunit of pyruvate dehydrogenase was also increased threefold $(P<0.005)$ (Figure 4b). Identical results were found for Irs2 $2^{-1-}$ : rip $13 \rightarrow$ Irs 2 islets. Since the secretion of insulin is tightly coupled to the rate of glucose metabolism, increased activity of glycolytic enzymes is consistent with improved $\beta$ cell function (27).

Irs 2 in $\beta$ cells prevents diabetes in obese and old mice. Peripheral insulin resistance develops during obesity and aging in mice and people, and progresses to diabetes when $\beta$ cells fail to compensate with increased insulin secretion (28). To determine whether expression of Irs 2 in $\beta$ cells promotes compensation for obesityinduced diabetes, WT C57BL/ 6 mice or rip $13^{\text {Irs2 }}$ mice were weaned and maintained for 60 days on a low- or a high-fat diet. Mice fed the high-fat diet were obese at 12 weeks of age $(\mathrm{C} 57 \mathrm{BL} / 6: 36.5 \pm 2.7 \mathrm{~g}, n=6 ;$ rip $13 \rightarrow$ Irs2 : $37.3 \pm 2.5 \mathrm{~g}, n=6)$ compared with those eating a low-fat $\operatorname{diet}(\mathrm{C} 57 \mathrm{BL} / 6: 24.6 \pm 2.8 \mathrm{~g}, n=6$; rip $13 \rightarrow$ Irs $2: 25.4 \pm 2.6 \mathrm{~g}$, $n=6)$. Obese mice displayed fasting hyperglycemia (obese C57BL/6: $206 \pm 16 \mathrm{mg} / \mathrm{dl}$; lean C57BL/6: $101 \pm 18 \mathrm{mg} / \mathrm{dl}$ ) and glucose intolerance (Figure 4a). By 

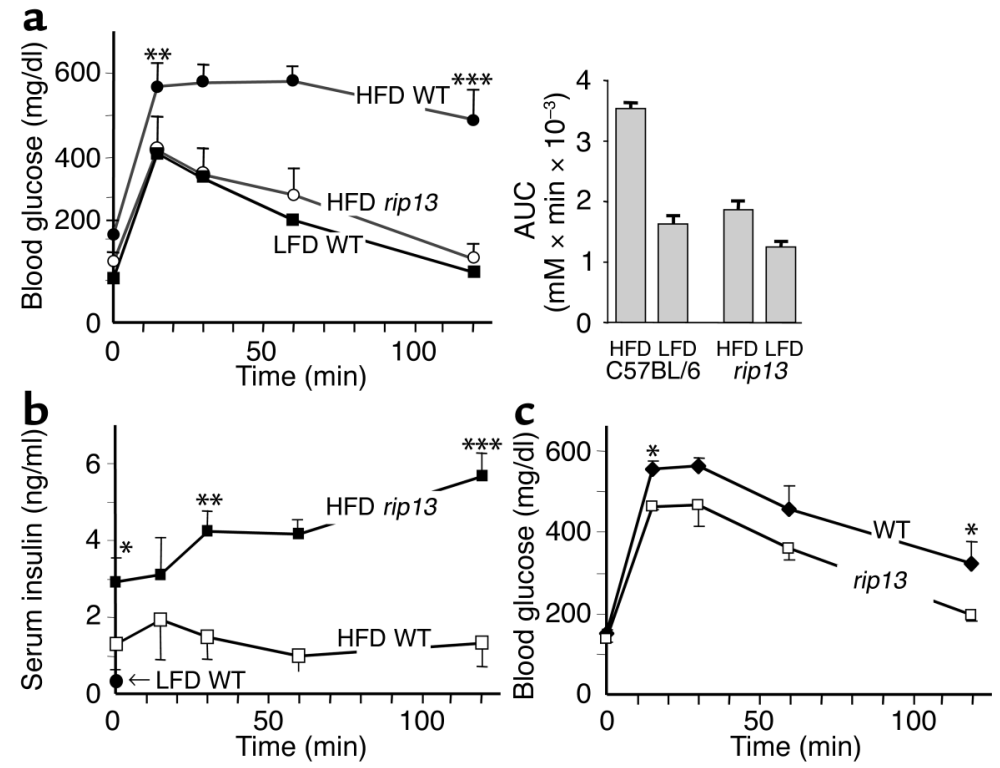

\section{Figure 5}

Metabolic characterization of WT and rip13 $\rightarrow$ /rs 2 mice maintained on a low-fat diet (LFD) or high-fat diet (HFD). (a) An intraperitoneal glucose tolerance test (2 g D-glucose per kg body wt) was performed on fasted $\mathrm{C} 57 \mathrm{BL} / 6$ WT or rip $13 \rightarrow$ rs 2 mice maintained on a high-fat or low-fat diet for 60 days after weaning. Blood samples were taken at the timepoints indicated and glucose levels were determined as described. Results are expressed as mean \pm SEM of six WT and six rip13 $\rightarrow$ rs 2 male mice $\left({ }^{*} P<0.01,{ }^{*}{ }^{*} P<0.001\right)$. (b) Serum insulin levels for the indicated timepoints during a glucose tolerance test. Data are the mean values \pm SEM $\left({ }^{*} P<0.05,{ }^{*} P<0.01,{ }^{*} *{ }^{*} P<0.001\right)$. (c) Glucose tolerance test in 6-month-old C57BL/ 6 WT and rip13 $\rightarrow$ rs 2 mice. Data are the mean values \pm SEM of eight mice per genotype ( $\left.{ }^{*} P<0.05\right)$. contrast, obese rip1 $13^{I r s}$ mice had statistically normal fasting glucose levels $(129 \pm 15 \mathrm{mg} / \mathrm{dl})$ and normal glucose tolerance (Figure 5a). Consistent with these results, fasting hyperinsulinemia was greater in obese rip13 $3^{\text {Irs } 2}$ mice than in obese C57BL/6 WT mice, and during the intraperitoneal glucose challenge insulin levels increased significantly in obese rip $13 \rightarrow I r s 2$ mice but not in obese C57BL/6 WT mice (Figure 5b).

Irs 2 expression falls as mice age (10). At 6 months, C57BL/ 6 mice on a normal diet developed mild glucose intolerance, whereas the rip $13 \rightarrow[r s 2$ mice were normal (Figure 5c). At 40 weeks, islet area was $3.1 \% \pm 0.6 \%$ in WT mice, $6 \% \pm 1 \%$ in rip $9 \rightarrow$ Irs 2 mice, and $10 \% \pm 2 \%$ in rip $13 \rightarrow I r s 2$ mice, revealing a graded response to a low and high level of Irs2 expression. Thus, transgenic Irs2mediated $\beta$ cell expansion compensates for insulin resistance that develops during aging.

Irs 2 promotes $\beta$ cell survival signaling. Acute or chronic stress and autoimmune responses upregulate proinflammatory cytokines (including TNF- $\alpha$, IL- $1 \beta$, and IFN- $\gamma$ ) that promote destruction of $\beta$ cells at least in part by contributing to apoptosis (29-32). By contrast, Irs protein signaling promotes cell growth and inhibits apoptosis in various cellular backgrounds (19).

\section{Figure 6}

IGF1 and insulin signaling in isolated islets. (a) Islets were isolated from WT or Irs2-/- C57BL/ 6 mice and incubated overnight before stimulation with insulin or IGF1 for 20 minutes as described in Methods. Each lane was loaded with $100 \mu \mathrm{g}$ of total islet protein. The results are representative of at least three independent experiments. (b) Islets were isolated from WT, Irs $2^{-/-}:$rip $13 \rightarrow \mid r s 2$, and rip $13 \rightarrow$ rs 2 mice and incubated overnight before stimulation with IGF1 for 20 minutes as described in Methods. The same amount of total protein $(300 \mu \mathrm{g})$ was loaded onto the gel and transferred to a nitrocellulose membrane. Membranes were analyzed for the presence of Erk1/2 and phosphorylated Erk (pErk1/2); Akt1/2 and phosphorylated Akt (pAkt1/2); Foxo1 and phosphorylated Foxo1 (pFoxo1); and cleaved caspase-3 (Casp3).
In isolated WT murine islets, IGF1 stimulated phosphorylation of Erk1/2, Akt, and the Akt target Foxo1 (Figure 6a). By contrast, in Irs $2^{-/-}$islets the phosphorylation of these targets was reduced, and cleaved/ activated caspase- 3 accumulated and was insensitive to IGF1 stimulation, which is consistent with decreased growth and survival of Irs2 $2^{--} \beta$ cells (Figure $6 a)$. To determine whether upregulation of Irs 2 restores these signals, islets were isolated from WT mice, or Irs $2^{--}$:rip $13^{\rightarrow I r s 2}$ and rip $13^{\rightarrow I r s 2}$ mice, cultured for 12 hours, and stimulated with IGF1. IGF1 stimulated phosphorylation of Erk1/2, Akt, and Foxo 1 in WT islets; however, the basal and IGF1-stimulated phosphorylation of these proteins was significantly increased in Irs2 $2^{--}$:rip $13^{\rightarrow I r s 2}$ and rip13 $\rightarrow$ Irs2 islets (Figure 6b). Moreover, upregulation of Irs2 eliminated the accumulation of cleaved cascapse-3, even before IGF1 stimulation, suggesting that Irs2 signaling plays a critical role in $\beta$ cell survival (Figure 6b).

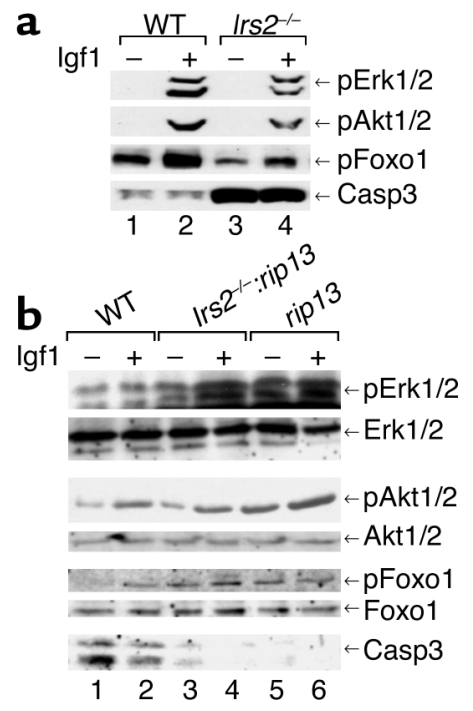




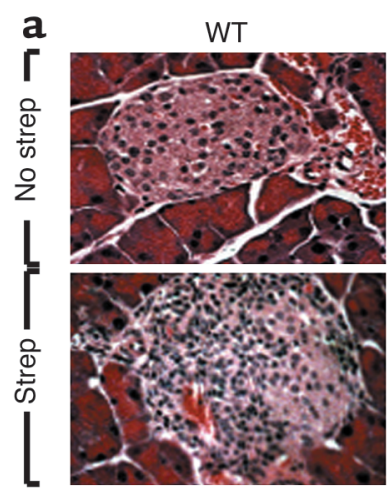

C
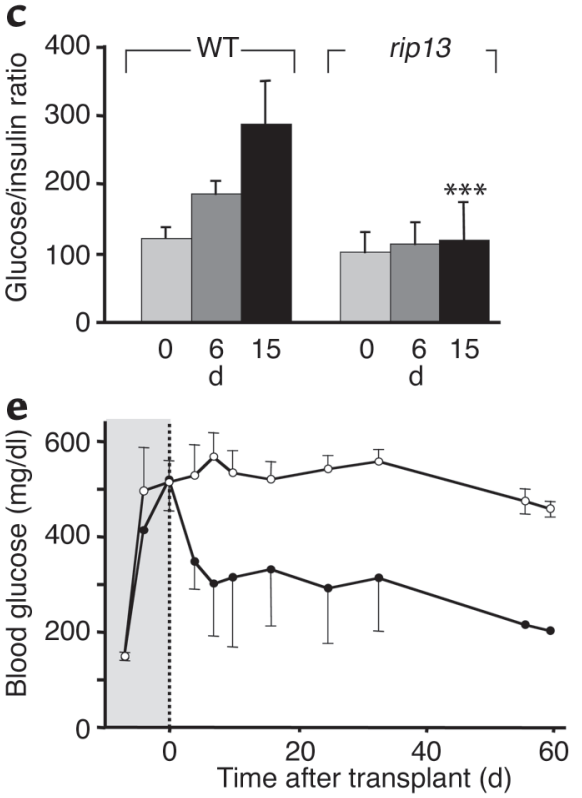
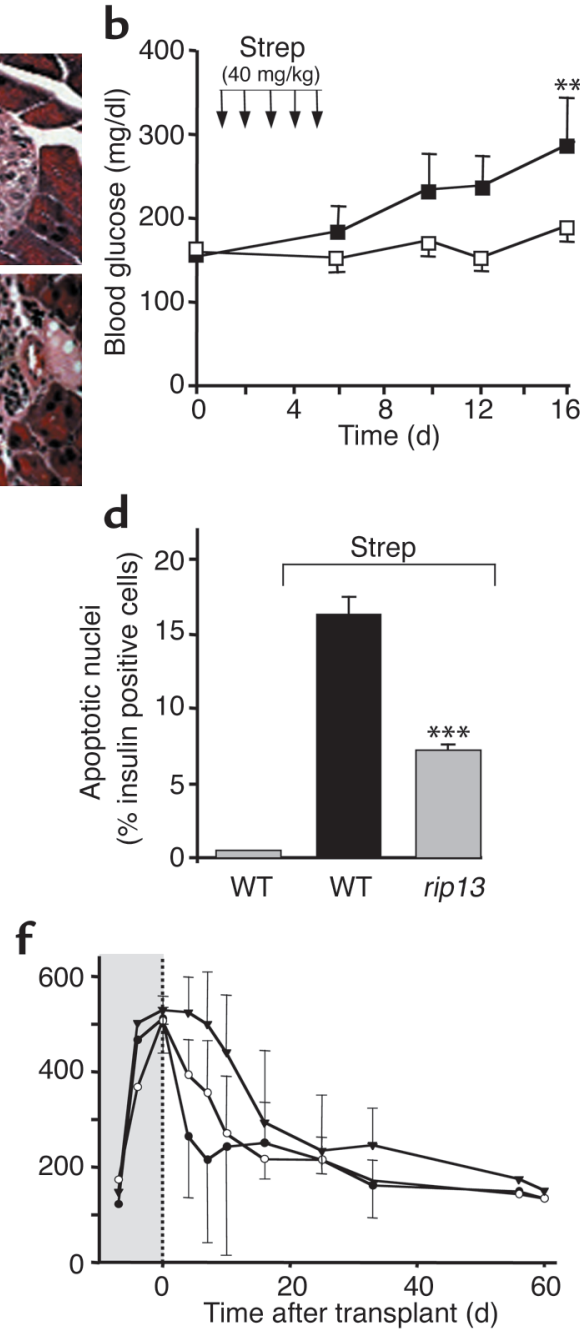

Figure 7

Survival and function of rip $13^{\rightarrow / r 2}$ mice during streptozotocin-induced diabetes. (a) Representative H\&E-stained pancreas sections from untreated WT or rip $13^{\text {Irs } 2}$ islets compared with pancreas sections obtained 15 days after one injection per day for 5 days of low-dose $(40 \mathrm{mg} / \mathrm{kg}$ ) streptozotocin (strep; original magnification, $\times 200)$. (b) Blood glucose levels in WT or rip13 $\rightarrow$ Irs 2 mice were measured before and after five (daily) injections of low-dose $(40 \mathrm{mg} / \mathrm{kg})$ streptozotocin. Results are expressed as mean \pm SEM of eight WT and eight rip13 $\rightarrow$ rs 2 mice $(* *<0.01)$; (c) Glucose levels $(\mathrm{mg} / \mathrm{dl})$ divided by serum insulin levels $(\mathrm{ng} / \mathrm{dl})$ are shown for experimental days 0 , 6, and $15(* * P<0.001)$. (d) Apoptotic cells were detected in deparaffinized sections using a rhodamine DNA fragmentation detection assay. The number of apoptotic nuclei per $\beta$ cell is shown for day 15 . Values are expressed as mean \pm SEM of eight WT and eight transgenic mice $(* * * P 0.001)$. (e) Transplantation of WT islets into streptozotocin-diabetic mice. C57BL/ 6 mice were treated with $100 \mathrm{mg} / \mathrm{kg}$ streptozotocin for 3 consecutive days. Blood glucose levels were measured in samples obtained through tail bleeds of fed mice before transplantation (shaded area) and at the indicated ages after transplantation of 300 (filled circles) or 150 (open circles) WT islets. (f) Transplantation of rip 13 $\rightarrow$ rrs 2 islets into streptozotocin-diabetic mice was conducted in identical fashion with 250 (filled circles), 120 (open circles), or 50 (inverted triangles) islets. Values are mean \pm SEM of at least three mice per experiment.

Apoptosis and function of rip13 $\rightarrow$ Irs 2 islets transplanted in mice. Since recombinant Irs 2 dramatically reduced the level of cleaved caspase-3, we reasoned that $\beta$ cell apoptosis might be reduced in rip $13^{\rightarrow \text { Irs } 2}$ islets. We induced $\beta$ cell apoptosis in situ by injecting a low dose of streptozotocin for 5 consecutive days into 8-week-old WT or rip $13 \rightarrow$ Irs 2 mice with comparable body weight $(21.7 \pm 3 \mathrm{~g})$ and comparable levels of random-fed serum glucose $(158 \pm 11 \mathrm{mg} / \mathrm{dl})$ and plasma insulin $(255 \pm 60 \mathrm{pmol} / \mathrm{l})$. Blood glucose and serum insulin levels were measured before streptozotocin injection and 6, 12, and 15 days after the first streptozotocin injection. At 15 days, $T$ cell infiltration was comparable in $\mathrm{C} 57 \mathrm{BL} / 6 \mathrm{WT}$ and rip $13^{\rightarrow \text { Irs } 2}$ mice (Figure 7a). However, low-dose streptozotocin caused insulinopenic diabetes in C57BL/6 WT mice, whereas the rip13 $\rightarrow$ Irs 2 mice were normal (Figure 7 , $\mathrm{b}$ and $\mathrm{c}$ ). Apoptotic $\beta$ cells were readily detected in WT mice, but apoptosis was reduced more than $50 \%$ in rip $13 \rightarrow$ Irs 2 mice (Figure $7 \mathrm{~d}$ ). Thus, transgenic Irs2 prevented the onset of diabetes 15 days after streptozotocin injection, at least in part by suppressing $\beta$ cell apoptosis.

To test whether rip13 $\rightarrow$ Irs 2 islets are resistant to the effects of stress induced by transplantation, WT or rip $13 \rightarrow$ Irs2 islets were transplanted under the kidney 
capsule of streptozotocin-diabetic mice. In this experiment, 8-week-old C57BL/6 mice were treated with $100 \mathrm{mg} / \mathrm{kg}$ streptozotocin for 3 consecutive days to cause severe diabetes (Figure 7, e and f). Without islet transplantation, the diabetic mice died about 10 days after the first injection. By contrast, transplantation of $300 \mathrm{WT}$ islets ( $>10,000$ islets $/ \mathrm{kg}$ ) normalized random-fed glucose levels by $50 \%$ within 3-5 days, and glucose levels were nearly normal 60 days later when the experiment was terminated (Figure 7e). By contrast, transplantation of $150 \mathrm{WT}$ islets prevented death but failed to normalize glucose levels (Figure $7 \mathrm{e}$ ), whereas 80 islets were completely ineffective as the diabetic mice died (not shown). Importantly, 50 rip13 $\rightarrow$ Irs 2 islets ( $\beta$ cell mass equivalent to $80 \mathrm{WT}$ islets) normalized random-fed glucose levels by $50 \%$ after 20 days, and quicker treatment was obtained with 120 and 250 rip13 $\rightarrow$ Irs 2 islets (Figure 7f). BrdU incorporation measured in the islet grafts 60 days after transplantation revealed that DNA synthesis was twofold greater in rip $13 \rightarrow$ Irs 2 islets $(2.12 \% \pm 0.32 \% \mathrm{BrdU}$ positive $\beta$ cells, $n=3)$ than in WT islets $(1.2 \% \pm 0.2 \%$ BrdU positive $\beta$ cells, $n=3$ ). Thus, upregulation of Irs 2 in transplanted $\beta$ cells significantly reduced the number of islets needed to cure diabetes in mice, at least in part by promoting proliferation.

\section{Discussion}

The primary cause of type 2 diabetes is unknown; however, there is general agreement that insulin resistance is an early event in the onset of the disease $(2,33)$. Many insulin-resistant patients secrete sufficient insulin for many years before $\beta$ cell function fails to compensate and type 2 diabetes emerges $(2,34,35)$. Systemic failure of Irs 2 in mice causes peripheral insulin resistance followed by $\beta$ cell failure and diabetes, although the time interval is compressed relative to human type 2 diabetes (36). Here we show that upregulation of Irs2 exclusively in $\beta$ cells promotes glucose tolerance in old mice and prevents diabetes in Irs $2^{-/-}$and obese mice. Moreover, IRS 2 protects $\beta$ cells from destruction by streptozotocin and improves the function of isolated $\beta$ cells used for transplantation. Thus, upregulation of Irs 2 in $\beta$ cells might be a common mechanism to prevent or treat many forms of diabetes.

Massive destruction of $\beta$ cells is well known in type 1 diabetics, and human autopsy studies reveal that $\beta$ cell mass is reduced at least $50 \%$ in obese patients with type 2 diabetes $(37,38)$. Thus, insufficient $\beta$ cell mass relative to peripheral requirements might be a key pathogenic factor of both types of diabetes (38). One way to preserve $\beta$ cell mass is to reduce apoptosis $(25,39)$. Streptozotocin in multiple low doses induces $\beta$ cell apoptosis and diabetes in mice and other mammals, at least in part by promoting $\mathrm{T}$ cell infiltration that promotes the production of TNF- $\alpha$ and IFN- $\gamma$ in the pancreas $(40,41)$. Upregulation of Irs 2 in mouse $\beta$ cells does not reduce $T$ cell infiltration during streptozotocin treatment; however, it reduces apoptosis of $\beta$ cells by $50 \%$, and prevents the onset of diabetes for at least 15 days. Several pathways promote survival of $\beta$ cells, and many of these mechanism are mediated by insulin/IGF1 $\rightarrow$ Irs2 signaling (19). Moreover, Irs2 signaling mediates the phosphorylation of $\mathrm{Bad}$ and the forkhead transcription factor Foxo1, which control important survival pathways $(42,43)$. The activation of Akt is an important mechanism used by insulin and IGF1 to inhibit apoptosis in a variety of cellular environments (44). Recent results suggest that Akt2 might promote $\beta$ cell survival by linking Irs 2 to Foxo1, especially during cytokine-induced stress (8).

Phosphorylated Bad dissociates from the antiapoptotic protein $\mathrm{Bcl} 2$, which inhibits activation of the caspase cascade, including the accumulation of the cleaved/activated effector caspase-3, which promotes apoptosis (42). IGF1 or insulin stimulation ordinarily inhibits the accumulation of cleaved/activated caspase3 through activation of Akt; however, insulin- and IGF1-stimulated Akt phosphorylation is reduced in Irs $2^{-/-}$islets, increasing the accumulation of cleaved/ activated caspase-3 that promotes $\beta$ cell apoptosis (19). IGF1 stimulation weakly reduces the levels of cleaved/ activated caspase- 3 in our WT isolated islets, consistent with low or undetectable Irs2 levels following overnight incubations. However, transgenic upregulation of Irs 2 almost completely blocks the accumulation of activated caspase-3, even before addition of exogenous IGF1. Thus, Irs2 is an important inhibitor of caspase-mediated apoptosis.

Foxo1 is an important Akt substrate that links insulin/IGF signaling to gene regulation (43). Phosphorylated Foxo1 is ordinarily excluded from the nucleus, which changes the expression of various genes including the upregulation of $P d x 1$ (10). $P d x 1$ plays an important role in gut and $\beta$ cell development, and promotes glucose sensing and insulin secretion in adult $\beta$ cells (45-47). Partial $P d x 1$ deficiency leads to an organlevel defect in insulin secretion and diabetes (25). Transgenic upregulation of Foxo1 constitutively increases the level of nuclear Foxo1, which downregulates $P d x 1$ and impairs $\beta$ cell function (10). By contrast, reduced expression of $P d x 1$ in $I r s 2^{-/-}$islets is consistent with nuclear accumulation of dephosphorylated Foxo1, whereas increased $P d x 1$ levels in Irs $2^{-/-}$:Foxo $1^{+/-}$islets reflect the reduced content of cellular Foxo1 (10). Similarly, upregulation of Irs 2 in rip $13^{\rightarrow I r s 2}$ or Irs2 $2^{-/}$:rip $13^{\rightarrow \text { Irs } 2} \beta$ cells increases Foxo1 phosphorylation to promote its exclusion from the nucleus, which is consistent with elevated $P d x 1$. Thus, $P d x 1$ might mediate many of the effects of Irs 2 in $\beta$ cells, as transgenic upregulation of $P d x 1$ restores $\beta$ cell function and promotes normal glycemia in Irs $2^{-/-}$mice (18). Interestingly, $P d x 1$ expression persists in some lines of C57BL/ 6 mice lacking Irs2, which protects them from diabetes (48).

Whether Irs 2 signaling promotes $\beta$ cell growth is difficult to determine. Before birth, Irs2 signaling is not required for $\beta$ cell development, as Irs $2^{-/-}$neonates have sufficient islet function to avoid diabetes for the 
first 8 weeks of life. However, $\beta$ cell mass fails to expand in Irs $2^{-/-}$mice even though peripheral insulin resistance is expected to promote expansion as it does in Irs $1^{-/-}$mice (9). Alone, upregulation of Irs2 does not increase mitogenesis in $\beta$ cells; however, islet density increases equally in both rip $13^{\rightarrow I r s 2}$ and Irs2 $2^{-/}$:rip $13^{\rightarrow I r s 2}$ mice. Alternatively, BrdU labeling is detectable in Irs2--rip13 $\rightarrow$ Irs 2 mice, suggesting that insulin resistance mediates $\beta$ cell mitogenesis through Irs 2 signaling. Unfortunately, our experiments do not reveal the mechanism by which Irs 2 increases islet density. However, Kitamura et al. suggest that nuclear exclusion of Foxo 1 from ductal precursors might promote the formation of new duct-associated islets by upregulating $P d x 1$ (10). Thus, relative hyperinsulinemia during the initial response to insulin resistance might promote Irs2-mediated $\beta$ cell growth. Unfortunately, this mechanism is expected to eventually fail, as Irs 2 signaling diminishes during progressive insulin resistance.

Although our work focuses on murine $\beta$ cells, preliminary experiments show that upregulation of IRS 2 in isolated human islets by adenoviral-mediated infection increases glucose-stimulated insulin release and BrdU incorporation (data not shown). Thus, pharmacologic or genetic approaches that upregulate Irs 2 in $\beta$ cells or promote Irs2-mediated downstream signals, such as reduction of nuclear Foxo1, might also improve $\beta$ cell function in people. Tools to upregulate Irs 2 have not been available because the regulation of Irs 2 gene expression is poorly studied. However, results with HeLa cells suggest that human IRS2 is moderately upregulated by cAMP and strongly upregulated by progesterone or the combination of cAMP and RU486 (49).

In our experiments, glucagen-like peptide 1 , exendin4 or dibutyl-cAMP strongly upregulated Irs 2 protein in Min $6 \beta$ cells, and similar results were observed with isolated human islets (data not shown). A mechanism for the regulation of Irs 2 by cAMP was recently suggested by Jhala et al., who demonstrated a functional CRE in the murine Irs2 gene (21). Thus, the trophic effect of GLP1/exendin-4 in rodents and people might be explained, at least in part, by the upregulation of IRS2 $(50,51)$. GLP1 secretion decreases in people with type 2 diabetes, but subcutaneous administration of GLP1 improves glucose homeostasis; lowers body weight, hemoglobin $\mathrm{A}(1 \mathrm{C})$, and free fatty acids; and increases insulin sensitivity and insulin action $(52,53)$. Moreover, GLP1/exendin-4 inhibits both cytokine and fatty acid-induced apoptosis in $\beta$ cells, and delays the development of diabetes in Zucker diabetic fatty rats by reducing $\beta$ cell loss (54). Since these changes are also expected upon increased Irs2 protein levels, GLP1/ exendin- 4 or other $\beta$ cell-specific cAMP agonists might prevent $\beta$ cell failure by promoting Irs 2 signaling.

As absolute or relative insulin insufficiency is associated with all forms of diabetes, $\beta$ cell replacement via transplantation represents an attractive alternative for treating human diabetics; however, the isolation of sufficient (at least 10,000 islets $/ \mathrm{kg}$ ) high-quality human islets that survive and function after transplantation is challenging (55). Given the capacity of the rip $13^{\rightarrow I r s 2}$ transgene to preserve or enhance $\beta$ cell function during transplantation in mice, upregulation of IRS2 by pharmacologic or genetic approaches just before transplantation might improve the function of human islets and reduce the number needed for successful transplantation.

In summary, upregulation of Irs 2 in $\beta$ cells disrupts disease progression in mice, and if expressed highly enough, can prevent the onset of diabetes caused by Irs 2 disruption or diet-induced obesity. The Irs 2 signaling system includes many elements that propagate the insulin/IGF signal to cytoplasmic regulatory enzymes and to nuclear regulatory elements. In $\beta$ cells, this includes certain MODY genes, revealing an intriguing link between insulin signaling and autosomal early onset diabetes $(10,18)$. Further investigation of the Irs2 branch of the insulin/IGF signaling cascade might explain the relationship between $\beta$ cell failure and peripheral insulin resistance that causes type 2 diabetes. If the IRS2 signaling cascade is a master regulator that integrates $\beta$ cell function with peripheral insulin action, upregulation of IRS2 by nutritional, pharmacologic, or genetic intervention could be a general way to slow progression or prevent the onset of diabetes.

\section{Acknowledgments}

The work was supported by grants from the NIH (R01DK55326-04 to M.F. White) and the Deutsche Forschungsgemeinschaft (HE-3321 to A.M. Hennige) as well as by the Juvenile Diabetes Foundation (J. Ye). M.F. White is an associate investigator at the Howard Hughes Medical Institute.

1. Zimmet, P., Alberti, K.G., and Shaw, J. 2001. Global and societal implications of the diabetes epidemic. Nature. 414:782-787.

2. Taylor, S.I., Accili, D., and Imai, Y. 1994. Insulin resistance or insulin deficiency. Which is the primary cause of NIDDM? Diabetes. 43:735-740.

3. Kahn, S.E. 2003. The relative contributions of insulin resistance and beta-cell dysfunction to the pathophysiology of type 2 diabetes. Diabetologia. 46:3-19.

4. Ehrmann, D.A., et al. 2002. Insulin secretory responses to rising and falling glucose concentrations are delayed in subjects with impaired glucose tolerance. Diabetologia. 45:509-517.

5. Kitamura, T., Kahn, C.R., and Accili, D. 2003. Insulin receptor knockout mice. Annu. Rev. Physiol. 65:313-332.

6. Yenush, L., and White, M.F. 1997. The IRS-signalling system during insulin and cytokine action. Bioessays. 19:491-500.

7. Kido, Y., Nakae, J., and Accili, D. 2001. Clinical review 125: the insulin receptor and its cellular targets. J. Clin. Endocrinol. Metab. 86:972-979.

8. Garofalo, R.S., et al. 2003. Severe diabetes, age-dependent loss of adipose tissue, and mild growth deficiency in mice lacking Akt2/PKB $\beta$. J. Clin. Invest. 112:197-208. doi:10.1172/JCI200316885.

9. Withers, D.J., et al. 1998. Disruption of IRS-2 causes type 2 diabetes in mice. Nature. 391:900-904.

10. Kitamura, T., et al. 2002. The forkhead transcription factor Foxo1 links insulin signaling to $P d x 1$ regulation of pancreatic $\beta$ cell growth. J. Clin. Invest. 110:1839-1847. doi:10.1172/JCI200216857.

11. Kulkarni, R.N., et al. 2002. beta-cell-specific deletion of the Igf1 receptor leads to hyperinsulinemia and glucose intolerance but does not alter beta-cell mass. Nat. Genet. 31:111-115.

12. Kulkarni, R.N., et al. 1999. Tissue-specific knockout of the insulin receptor in pancreatic $\beta$ cells creates an insulin secretory defect similar to that in type 2 diabetes. Cell. 96:329-339.

13. Xuan, S., et al. 2002. Defective insulin secretion in pancreatic $\beta$ cells lacking type 1 IGF receptor. J. Clin. Invest. 110:1011-1019. doi:10.1172/ JCI200215276.

14. Bonner-Weir, S. 2000. Islet growth and development in the adult. J. Mol. Endocrinol. 24:297-302. 
15. Avruch, J. 1998. A signal for b-cell failure. Nature. 391:846-847.

16. Ehrmann, D.A., Tang, X., Yoshiuchi, I., Cox, N.J., and Bell, G.I. 2002. Relationship of insulin receptor substrate- 1 and -2 genotypes to phenotypic features of polycystic ovary syndrome. J. Clin. Endocrinol. Metab. 87:4297-4300.

17. Sutton, R., Peters, M., McShane, P., Gray, D.W., and Morris, P.J. 1986. Isolation of rat pancreatic islets by ductal injection of collagenase. Transplantation. 42:689-691.

18. Kushner, J.A., et al. 2002. Pdx1 restores beta cell function in Irs2 knockout mice. J. Clin. Invest. 109:1193-1201. doi:10.1172/JCI200214439.

19. Withers, D.J., et al. 1999. Irs-2 coordinates Igf-1 receptor-mediated betacell development and peripheral insulin signalling. Nat. Genet. 23:32-40.

20. Flier, S.N., Kulkarni, R.N., and Kahn, C.R. 2001. Evidence for a circulating islet cell growth factor in insulin-resistant states. Proc. Natl. Acad. Sci. U. S. A. 98:7475-7480.

21. Jhala, U.S., et al. 2003. cAMP promotes pancreatic beta-cell survival via CREB-mediated induction of IRS2. Genes Dev. 17:1575-1580.

22. Previs, S.F., Withers, D.J., Ren, J.M., White, M.F., and Shulman, G.I. 2000 Contrasting effects of IRS-1 vs. IRS-2 gene disruption on carbohydrate and lipid metabolism in vivo. J. Biol. Chem. 275:38990-38994.

23. Jonsson, J., Carlsson, L., Edlund, T., and Edlund, H. 1994. Insulin-promoter-factor 1 is required for pancreas development in mice. Nature. 371:606-609.

24. Stoffers, D.A., Zinkin, N.T., Stanojevic, V., Clarke, W.L., and Habener, J.F. 1997. Pancreatic agenesis attributable to a single nucleotide deletion in the human IPF1 gene coding sequence. Nat. Genet. 15:106-110.

25. Johnson, J.D., et al. 2003. Increased islet apoptosis in $P d x 1^{+/-}$mice. J. Clin Invest. 111:1147-1160. doi:10.1172/JCI200316537.

26. Ahlgren, U., Jonsson, J., Jonsson, L., Simu, K., and Edlund, H. 1998. betacell-specific inactivation of the mouse Ipf1/Pdx1 gene results in loss of the beta-cell phenotype and maturity onset diabetes. Genes Dev. 12:1763-1768.

27. Yoon, J.C., et al. 2003. Suppression of beta cell energy metabolism and insulin release by PGC-1alpha. Dev. Cell. 5:73-83.

28. Matthews, D.R., et al. 1985. Homeostasis model assessment: insulin resistance and beta-cell function from fasting plasma glucose and insulin concentrations in man. Diabetologia. 28:412-419.

29. Hammonds, P., et al. 1990. Insulin-secreting beta-cells possess specific receptors for interleukin-1 beta. Growth Regul. 261:97-100.

30. Zumsteg, U., et al. 1993. Differential interleukin-1 receptor antagonism on pancreatic beta and alpha cells. Studies in rodent and human islets and in normal rats. Diabetologia. 36:759-766.

31. Mandrup-Poulsen, T., Bendtzen, K., Dinarello, C.A., and Nerup, J. 1987. Human tumor necrosis factor potentiates human interleukin 1-mediated rat pancreatic beta-cell cytotoxicity. J. Immunol. 139:4077-4082.

32. Suarez-Pinzon, W.L., Strynadka, K., Schulz, R., and Rabinovitch, A. 1994. Mechanisms of cytokine-induced destruction of rat insulinoma cells: the role of nitric oxide. Endocrinology. 134:1006-1010.

33. Shulman, G.I. 2000. Cellular mechanisms of insulin resistance. J. Clin. Invest. 106:171-176.

34. Reaven, G.M. 2002. Multiple CHD risk factors in type 2 diabetes: beyond hyperglycaemia. Diabetes Obes. Metab. 4(Suppl. 1):S13-S18.

35. Reaven, G.M. 2001. Insulin resistance: why is it important to treat? Diabetes Metab. 27:247-253.

36. White, M.F. 2002. IRS proteins and the common path to diabetes. Am. J. Physiol. Endocrinol. Metab. 283:E413-E422.
37. Clark, A., et al. 1988. Islet amyloid, increased A-cells, reduced B-cells and exocrine fibrosis: quantitative changes in the pancreas in type 2 diabetes. Diabetes Res. 9:151-159.

38. Butler, A.E., et al. 2003. Beta-cell deficit and increased beta-cell apoptosis in humans with type 2 diabetes. Diabetes. 52:102-110.

39. Pick, A., et al. 1998. Role of apoptosis in failure of $\beta$-cell mass compensation for insulin resistance and $\beta$-cell defects in the male Zucker diabetic fatty rat. Diabetes. 47:358-364.

40. Herold, K.C., et al. 1996. Regulation of cytokine production during development of autoimmune diabetes induced with multiple low doses of streptozotocin. J. Immunol. 156:3521-3527.

41. Holstad, M., and Sandler, S. 2001. A transcriptional inhibitor of TNFalpha prevents diabetes induced by multiple low-dose streptozotocin injections in mice. J. Autoimmun. 16:441-447.

42. Brazil, D.P., and Hemmings, B.A. 2001. Ten years of protein kinase B signalling: a hard Akt to follow. Trends Biochem. Sci. 26:657-664.

43. Tran, H., Brunet, A., Griffith, E.C., and Greenberg, M.E. 2003. The many forks in FOXO's road. Sci. STKE. 2003:RE5.

44. Datta, S.R., et al. 1997. Akt phosphorylation of BAD couples survival signals to the cell-intrinsic death machinery. Cell. 91:231-241.

45. Peers, B., Leonard, J., Sharma, S., Teitelman, G., and Montminy, M.R. 1994. Insulin expression in pancreatic islet cells relies on cooperative interactions between the helix loop helix factor E47 and the homeobox factor STF-1. Mol. Endocrinol. 8:1798-1806.

46. Watada, H., et al. 1996. The human glucokinase gene beta-cell-type promoter: an essential role of insulin promoter factor 1/PDX-1 in its activation in HIT-T15 cells. Diabetes. 45:1478-1488

47. Waeber, G., Thompson, N., Nicod, P., and Bonny, C. 1996. Transcriptional activation of the GLUT2 gene by the IPF-1/STF-1/IDX-1 homeobox factor. Mol. Endocrinol. 10:1327-1334.

48. Suzuki, R., et al. 2003. Pdx1 expression in Irs2 deficient mouse beta-cells is regulated in a strain-dependent manner. J. Biol. Chem. doi:10.1074/ jbc.M307004200

49. Vassen, L., Wegrzyn, W., and Klein-Hitpass, L. 1999. Human insulin receptor substrate-2 (IRS-2) is a primary progesterone response gene. Mol. Endocrinol. 13:485-494.

50. Holst, J.J. 2002. Therapy of type 2 diabetes mellitus based on the actions of glucagon-like peptide-1. Diabetes Metab. Res. Rev. 18:430-441.

51. Li, Y., et al. 2003. Glucagon-like peptide-1 receptor signaling modulates beta cell apoptosis. J. Biol. Chem. 278:471-478.

52. Lugari, R., et al. 2002. Evidence for early impairment of glucagon-like peptide 1 -induced insulin secretion in human type 2 (non insulin dependent) diabetes. Horm. Metab. Res. 34:150-154.

53. Zander, M., Madsbad, S., Madsen, J.L., and Holst, J.J. 2002. Effect of 6week course of glucagon-like peptide 1 on glycaemic control, insulin sensitivity, and beta-cell function in type 2 diabetes: a parallel-group study. Lancet. 359:824-830.

54. Farilla, L., et al. 2002. Glucagon-like peptide-1 promotes islet cell growth and inhibits apoptosis in Zucker diabetic rats. Endocrinology. 143:4397-4408

55. Goss, J.A., et al. 2002. Achievement of insulin independence in three consecutive type- 1 diabetic patients via pancreatic islet transplantation using islets isolated at a remote islet isolation center. Transplantation. 74:1761-1766. 